\title{
Impact of Fungicides on the Growth and Distribution of Soil Mycoflora in Agriculture Fields at Narasannapeta
}

\author{
Ratna Kumar P. K. ${ }^{1}$, Shiny Niharika P. ${ }^{2}$, Hemanth, G. ${ }^{3}$ \\ Department of Botany, Andhra University, Visakhapatnam-530003, Andhra Pradesh, India
}

\begin{abstract}
Pesticides have different undesired effects on soil diversity and functioning affecting microorganisms by reducing their numbers, biochemical activity, diversity and changing the microbial community structure. Eleven fungal species like Aspergillus flavus, A.niger, A.oryzaae, Curvularia lunata, Fusarium oxysporum, F.solani, Penicillium aurentiogriseum, P.chrysogenum, P.frequentans, Rhizopus stolonifer and Trichoderma harzianum were selected for the study. Three commercial fungicides i.e; Carbendazim, Copper Oxy Chloride and Mancozeb were used to study their effects on soil fungi. The study was conducted to determine the effects of fungicides application on soil fungal populations, at different application rates ranging from $1 / 2$ litre, 1 litre and with the control soil samples having no fungicide injection. A total of 282 colonies of 11 species were isolated from the control plates examined in 3 different crops (Rice, Black-Gram and Ground-Nut) of Narasannapeta Mandal, in Srikakulam District. 163 and 88 colonies only were isolated from the soils treated with $1 / 2$ and 1 Lt Carbandazim, 159 and 79 colonies from soils treated with $1 / 2$ and 1 Lt COC and 138 and 55 colonies from soils treated with $1 / 2$ and 1 Lt of Mancozeb, thus confirming Mancozeb as the most destructive. The results reveal that fungicide applications caused drastic reduction in microbial population present in the soils when compared with the control. Death of the micro-organisms deducts the decomposition of dead leaf material into its organic and inorganic constituents leading to reduction in the incorporation of organic matter into the soil structure thereby affecting the soil fertility.
\end{abstract}

Keywords: Mycology, Soil Fungi, Fungicides, Environmental Effect, Micro Organisms

\section{Introduction}

Pesticides are defined under the Federal Environmental Pesticide Control Act (FEPCA) as "any substance or mixture of substances intended for preventing, destroying, repelling or mitigating any pest (insects, rodents, nematodes, fungus, weeds and other forms of terrestrial or aquatic plant or animal like bacteria or other micro-organisms)" (Mishra., P.C. 2001). Continuous use and release of these synthetic chemicals has become everyday occurrence, and frequent systematic application of these to the soil may accumulate the recalcitrant chemicals that may possess permanent hostile effect on soil micro-biological and biochemical activities as they end up in the upper soil layers even if not applied directly resulting in environmental pollution. Among microbes, filamentous fungi dominate our globe as sources of food, plant and animal pathogens and for biosynthesis of other worthy products. The growth, survival, continuity and community of fungi are significantly affected by the application of hazardous chemicals to the cultivated lands. Fungicides are bio-toxicants which not only affect the biochemical and physiological reactions of plant pathogens but also influence populations of microorganisms in soil.

\section{Materials and Methods}

\section{Fungicides Used}

Fungicides are the chemical compounds used to preclude the spread of fungi or plants in crops and gardens which can drive serious damage resulting in loss of yield. Fungicides fight against fungal infections and control bacterial and fungal diseases. Some of the diseases that are controlled by using fungicides are mildew, leaf spots, blights and apple scab. There is a dreath of information on the side effects of fungicides on key soil ecological processes. The fungicides have the potential to cause major changes to soil mycoflora populations. It has been concluded by some authors that even a single application of fungicide at field application rates may cause lasting changes in nitrogen transformations and availability in soils (Anderson et al., 1981)

\section{Carbendazim}

Its chemical name is Methyl benzimidazol-2-ylcarbamate with molecular formula $\mathrm{C}_{9} \mathrm{H}_{9} \mathrm{~N}_{3} \mathrm{O}_{2}$. It is a systemic benzimidazole fungicide that plays a very important role in plant disease control. Dosage as recommended is 500gm and $1000 \mathrm{gm}$ diluted in $2000 \mathrm{ml}$ and $4000 \mathrm{ml}$ of water for $1 / 2 \mathrm{Lt}$ and $1 \mathrm{Lt}$ treatment respectively. It is manufactured by Coromandel International Limited, Secunderabad, Telangana.

\section{Copper Oxy Chloride (COC):}

It is a kind of fungicide which is effective and used for the control of fungus diseases of fruit trees, vines and vegetables, also helps in preventing black spot on apples, pears, tomatoes and citrus fruits . Its chemical formula is $3 \mathrm{Cu}(\mathrm{OH})_{2} \cdot \mathrm{CuCl}_{2}$. Dosage as recommended is $500 \mathrm{gm}$ and $1 \mathrm{Kg}$ diluted in $70 \mathrm{Lt}$ and $140 \mathrm{Lt}$ of water for $1 / 2 \mathrm{Lt}$ and $1 \mathrm{Lt}$ of treatment. The product is manufactured by Biota Agro Solutions Private Ltd, Via Kalamassery, Kochi.

\section{Mancozeb:}

Its chemical name is Manganese ethylene bis (dithiocarbamate) (polymeric) complex with zinc salt with molecular formula $\left[\mathrm{C}_{4} \mathrm{H}_{6} \mathrm{MnN}_{2} \mathrm{~S}_{4}\right] \mathrm{xZny}$. The dosage used was $500 \mathrm{gm}$ and $1 \mathrm{Kg}$ diluted in $70 \mathrm{Lt}$ and $140 \mathrm{Lt}$ of water for $1 / 2 \mathrm{Lt}$ and $1 \mathrm{Lt}$ of treatment. The product is a grayish-yellow powder with a musty odour. It is insoluble in water and other organic solvents. Mancozeb is a polymer of maneb combined with zinc, has low acute toxicity to mammals and 


\section{International Journal of Science and Research (IJSR) ISSN (Online): 2319-7064}

Index Copernicus Value (2015): 78.96 | Impact Factor (2015): 6.391

is not poisonous to plants. Manufactured by Indofil Industries Limited, Thane, Maharashtra.

The study was conducted in the farms of Narasannapeta. Initial Soil samples used in this investigation were collected for microbial analysis 20days after emergence of the plants. The samples were collected randomly from farm with auger from $0-20 \mathrm{~cm}$ depth. The samples collected without pesticide application were used as control, after which the fungicides were sprayed separately, in different sites. Three fungicides commonly used by the growers of the region were selected for the study. The samples were collected from the agricultural sites under rice, black-gram and ground-nut cultivation, 15-20 days after application of fungicides. The samples were taken to the laboratory and stored at temperature of $4^{\circ} \mathrm{C}$ until the analysis were conducted and completed. For the enumeration of micro-fungal population dilution plate count technique (DPCT) (Waksman, 1922) was followed. Eleven fungal species were selected for the study. Out of them 3 sp.belonged to genus Aspergillus, 3 belonged to Penicillium, 2 sp. belonged to Fusarium, $1 \mathrm{sp}$. belonged to Curvularia, Rhizopus and Trichoderma. Three commercial fungicides (Mancozeb, Carbendazim and COC), were used to study their effects on soil fungi Fig 8.

\section{Results}

The study was conducted to determine the effects of fungicides application on soil fungal populations, at different application rates ranging from 1/2litre, 1litre with the control soil samples having no fungicide injection. The results reveal that fungicide applications caused drastic reduction in microbial population present in the soils when compared with the control. The untreated soils had significantly higher fungal populations than the treated soils. A great difference was observed between microbial population in non treated control soil and treated soil with pesticide confirming the effects of microbial deduction and extinction due to indiscriminate use of pesticide in the soil. On the whole fungal species drastically reduced from the soil, due to pesticide infestation which was suspected to be the reason for poor yield on the farm. The result is consistent with the findings of Elain (2001) who observed that if the soil is void of micro-organisms, the soil is said to be dead. Hence this indiscriminate use of pesticides might work for few years, but after a while there will be no beneficial soil micro-organisms to hold on to nutrient. Primarily the soil without pesticides treatment was collected prior to fungicides application in order to observe the number of colonies produced by the selected 11 fungal species. The fungal diversity was examined in 3 different crops (Rice, Black-Gram and Ground-Nut) of Narasannapeta Mandal, in Srikakulam District. Table 1 shows the number of fungal isolates in the soil samples not treated with fungicides, and therefore was referred to as control. A total of 282 colonies of 11 species were isolated from the control plates. The fugal population varied from one crop to another with soil samples from rice crop having the total value of 101 colony counts with a mean value of 9.18 that constitutes $35.80 \%$ and black gram crop soil having total value of 85 colony counts with a mean value of 7.72 which constitutes to $30.14 \%$ and ground nut soils with a total of 96 colony counts and mean value of 8.72 which constitutes $34.04 \%$ variations.
However, there was no appreciable difference in the mean values of the fungal isolations between rice and ground nut sampled soils that are not treated with pesticides, where as little difference was seen with black gram soil samples. All the fungal species listed were present abundantly in the nontreated soils except Fusarium oxysporum, F.solani and Trichoderma harzianum which tend to be smaller in quantity. The highest percentage was that of Aspergillus niger (19.5\%) followed by Penicillium chrysogenum (16.31\%), A.flavus (15.24\%), P.aurentiogriseum (10.63\%), P.frequentans (10.28\%), Rhizopus stolonifer (7.09\%), A.oryzae, Curvularia lunata both equally with (6.02\%), Fusarium oxysporum (3.54\%), F.solani (2.83\%) and Trichoderma harzianum (2.48\%). The statistical analysis of the data with $\mathrm{p}$ value 0.820934 indicated the frequency and percentage contribution of the selected 11 fungal species from rice, black-gram and ground-nut field soils not treated with pesticides Table 2. The Simpson's Diversity Index was lowest in the rice fields $(0.1113)$ followed by ground nut (0.1145) and finally black-gram (0.1249). The Shannon's Index is highest in rice (3.227) followed by ground nut (3.192) and black-gram (3.12). This shows rice has the highest species diversity. The Dominance Index shows not much difference among the 3 crops studied. Menhinick's Index is high in black-gram followed by ground nut and then rice similarly Berger-Parker Dominance Index is also high in black gram (0.2) followed by ground nut (0.1979) and rice (0.1881). Margalef's Richness Index is high in black gram (2.251) followed by ground nut (2.191) and rice (2.167) which shows low species abundance in black gram and high species abundance in rice. The Equitability Index is lowest in black gram showing less species abundance in black gram Table 3 .

\section{Effect of fungicides}

Application of fungicide strongly decreased the fungal counts. It could be suggested that each type of fungicide has its own specific effect on the fungal species. The metabolic activities of the sensitive fungal species were affected. Soil treated with the fungicide shows the most adverse effect on fungal population. From the Fig 1, it is clear that, from the soils which were not treated with pesticides the most abundant spp. was A.niger followed by P.chrysogenum and the least percentage was that of T.harzianum followed by F.solani and F.oxysporum. Table 4 shows the number of fungi isolated in soil samples treated with half $(1 / 2)$ litre of fungicides Carbendazim, $\mathrm{COC}$ and Mancozeb. It was observed that the number of fungal species present in the sampled soils reduced due to injection of half $(1 / 2)$ litre of fungicides. In the soils treated with Mancozeb Fusarium oxysporum and Trichoderma harzianum were totally extinct in black gram and ground nut soils when compared to the control samples in Table 1. The difference in mean value of fungi isolated from sampled soils ie., rice, black gram and ground nut treated with half litre fungicide, were 5.63, 4.45 and 4.72 constituting to $38.03 \%, 30.06 \%$ and $31.90 \%$ for Carbendazim; and 5.63, 4.27 and 4.54 constituting a percentage of $38.99 \%, 29.55 \%$ and $31.44 \%$ for COC; and $4.72,3.63$ and 4.18 constituting a percentage of $37.68 \%$, $28.98 \%$ and $33.33 \%$ for Mancozeb respectively. The statistical analysis of the data where the level of probability with $\mathrm{p}$ values $0.652193,0.551987$, and 0.685113 nonsignificantly indicates the frequency of fungal colonies

\section{Volume 6 Issue 1, January 2017




\section{International Journal of Science and Research (IJSR) \\ ISSN (Online): 2319-7064 \\ Index Copernicus Value (2015): 78.96 | Impact Factor (2015): 6.391}

isolated from soil treated with $1 / 2$ LT fungicides Carbendazim, COC and Mancozeb respectively Tables 5, 6 \& 7. The mean values of all 3 fungicides, on rice, black gram and ground nut individually treated with $1 / 2 \mathrm{Lt}$ fungicides is depicted in Fig 2. Table 8 shows the number of fungi isolated in soil samples treated with 1 litre of fungicides Carbendazim, COC and Mancozeb. The species F.oxysporum became extinct from black gram soils, whereas F.solani was extinct from both rice and ground nut soils and T.harzianum was extinct form the ground nut soils when Carbendazim was used. During the test with COC it was observed that along with F.oxysporum, F.solani and T.harzianum, A.oryzae and C.lunata were also extinct. T.harzianum totally disappeared from all the three crop soil samples. From the Mancozeb treated soils; along with the above five spp. Penicillium aurentiogriseum had disappeared from black gram soils. Tolerance nature of certain fungi like A.flavus, A.niger, P.chrysogenum and $P$.frequentans etc,. were suspected to be influenced by the adaptability to stress caused due to pesticide application. From Table 8 it is evident that the reduction of the fungal spp. count based on 1litre pesticides was with greater impact than Table 4, with fungal variations of mean values of soils of rice, black gram and ground nut fields treated with 1LT fungicides were $3.18,2.45$ and 2.36 which constitutes a percentage of $39.77 \%, 30.68 \%$ and $29.54 \%$ for Carbendazim; and $2.81,2.09$ and 2.27 which constitutes percentage $39.24 \%, 29.11 \%$ and $31.64 \%$ for COC; and 1.81, 1.45 and 1.72 constituting percentage $36.36 \%, 29.09 \%$ and $34.54 \%$ for Mancozeb respectively in all three crop soil samples. The statistical analysis of the data with $\mathrm{p}$ values of $0.644569,0.741833$ and 0.880592 non significantly indicates the frequency of fungal colonies isolated from 3 field soils treated with $1 \mathrm{LT}$ fungicides Carbendazim, COC and Mancozeb respectively Table 9, 10 \& 11. The mean value of frequencies of 3 crops treated with 3 fungicides is depicted in Fig 3.

Through the study, soils of fungicides treated plants harboured less population than the control. Similar results have been reported by several other workers (Srivastava et al., 1970; Kuthubutheen 1979; Abdelfattah et al., 1982; Doneche et al., 1983). Among the three fungicides used, Mancozeb was proved to be more effective thereby destroying large number of fungal colonies contributing to the loss of fungal spp. On the whole when half litre fungicides were used the percentage in rice, black gram and ground nut soil samples were $38.26 \%, 29.56 \%$ and $32.17 \%$ respectively Fig 2 and when 1Lt were used 38.73\%, 29.72\% and $31.53 \%$ Fig 3 . The fungicide spray changes the fungal community structure and adversely affects various fungi mediated processes of soil. This may affect the processes of nutrient release. Among the fungicides Mancozeb was more effective on diminishing the fungal species followed by COC and then Carbendazim Fig 9. Out of the 282 colonies obtained from control soils, 163 and 88 colonies only were isolated from the soils treated with $1 / 2$ and 1 Lt Carbandazim. Out of these Fusarium oxysporium, F.solani and Trichoderma harzianum were almost at the verge of extinction. 159 and 79 colonies were isolated from soils treated with $1 / 2$ and $1 \mathrm{Lt} \mathrm{COC.} \mathrm{T.harzianum} \mathrm{was} \mathrm{extinct}$ while F.oxysporum and F.solani were near to extinction. A total of only 138 and 55 colonies were obtained from soils treated with $1 / 2$ and $1 \mathrm{Lt}$ of Mancozeb, thus confirming Mancozeb as the most destructive. In the Mancozeb treated soils along with F.oxysporum and F.solani, other 2 fungi Aspergillus oryzae and Curvularia lunata were also at verge of extinction, while T.harzianum was extinct. The individual frequencies of the 11 species were depicted in the Fig 4, 5 \& 6. The fungal populations in each of the three agricultural soils were significantly decreased drastically in the presence of fungicides Fig 7. Similar results had been reported for other fungicides (Pozo et al., 1994). The effects obtained in our studies may be influenced by the degree of soil disruption and also by the species of fungi present in the soils.

The Simpson's Diversity Index was highest in 1Lt Mancozeb in black gram (0.2424), 1Lt COC in Black Gram (0.2083) and 1Lt COC (0.1681) in rice indicating the less species diversity. The Simpson's Index was lowest in $1 \mathrm{Lt}$ Mancozeb (0.093) followed by $1 / 2 \mathrm{Lt}$ of Mancozeb (0.1018), $1 / 2 \mathrm{Lt}$ COC (0.102). The Shannon's Index is highest in $1 / 2 \mathrm{Lt}$ Mancozeb (3.239) and $1 / 2 \mathrm{Lt}$ Carbendazim (3.229) all in rice field showing the highest species diversity. The Donimance Index is highest in $1 \mathrm{Lt}$ Mancozeb (0.9064) in ground nut followed by $1 / 2 \mathrm{Lt}$ Mancozeb (0.8982) in rice and $1 / 2 \mathrm{Lt}$ COC (0.898) in ground nut indicating high species dominance and high diversity and lowest in 1Lt Mancozeb (0.7576) followed by 1 Lt COC (0.7917), both in black gram fields and $1 \mathrm{Lt} \mathrm{COC} \mathrm{(0.8319)}$ in rice field soils indicating less diversity. Menhinick's Index is high in 1Lt Mancozeb (2.065) in ground nut, 1Lt Carbendazim (1.925) in blackgram and then 1Lt COC (1.837) in ground nut showing low species richness and high diversity. Similarly BergerParker Dominance Index is also high in 1Lt COC (0.333) in rice field, 1Lt Mancozeb (0.416) and 1Lt COC (0.4375) both in black gram and is lowest in $1 / 2 \mathrm{Lt}$ Carbendazim (0.1613) and $1 / 2 \mathrm{Lt}$ COC (0.1774) in rice field soils. Margalef's Richness Index is high in blackgram treated with $1 \mathrm{Lt}$ Carbendazim (2.731) and the Index is low in case of $1 \mathrm{Lt}$ Mancozeb (1.61) in black gram and 1Lt COC (2.124) in rice field soils. This shows the low species abundance and high species abundance respectively. The Equitability Index is lowest in 1Lt COC (0.8369), 1/2Lt Mancozeb (0.8402) both in black gram field soils low species abundance and highest in $1 / 2 \mathrm{Lt}$ Mancozeb (0.9455) in ground nut followed by $1 \mathrm{Lt}$ Mancozeb (0.9372) in ground nut and $1 / 2 \mathrm{Lt}$ Mancozeb $(0.9363)$ in rice field soils indicating lowest and highest species evenness respectively Table 12.

\section{Discussion}

Microbial populations of soils are altered by the fungicides application (Wainwright 1977, 1978, Wainwright \& Pugh 1973, 1974, 1975 a, Kuthubutheen 1979, Torstensson 1979, Chandra et al. 1982, Torstensson\&Wessen 1984). Srivastava \& Dayal (1981) reported change in the structure of fungal community following fungicidal application. Shukla.A.K. et al., 1987, studied the effect of fungicides Benomyl, COC, and Mancozeb on bacterial and fungal population of rhizosphere and non-rhizosphere soils and observed that the microflora populations dropped significantly following application of the fungicides, and throughout the study the treated plots harboured lower populations than the control plots. Pozo et al. (1994) reported that total platable fungal 


\section{International Journal of Science and Research (IJSR) \\ ISSN (Online): 2319-7064}

Index Copernicus Value (2015): 78.96 | Impact Factor (2015): 6.391

populations were significantly decreased by agricultural doses of Mancozeb. Pankhurst et al., 1997 in their reports stated that the fungicide Mancozeb and the nematicide "aldicarb" when applied to soil individually did not affect the colonization of sugarcane roots by arbuscular mycorrhizal fungi, but reduced colonization when applied in combination. Brun et al. 1998 reported that prolonged use of copper fungicide application has lead to high levels in the soil (200-500 mg/kg in France) which has affected a large portion of agricultural land. Dumestre et al. 1999 reported that elevated concentrations of copper in soils are toxic and may result in a range of effects including reduced biological activity and subsequent loss of fertility. Maboeta et al. 2003 found that $\mathrm{COC}$ has recently been shown to reduce populations of the earthworm Aporrectodea caliginosa in field trials. Liao et al. 2003 also reported that elevated $\mathrm{Cu}$ concentrations have been shown to reduce beneficial mycorrhizal associations. Abhishekwalia et al. 2014., conducted experiments and found that fungal and actinomycetes populations decreased in Mancozeb treated soil at concentrations above $10 \mathrm{ppm}$ and degree of reduction is related to the amount of fungicide applied. The total nitrogen content of A.niger and P.chrysogenum was significantly retarded by the fungicide Afugan. Fungicides of broad continuum produce adverse consequences on nontarget organisms. Extensive use of fungicides may lead to the emergence of new resistant strains of pathogens. According to Mariusz Cycon and Zofia Piotrowska-Seget 2007 dosages used of Mancozeb + dimethomorph significantly decreased the numbers of fungi which is similar to the results obtained. Martinez-Toledo et al. 1998, Smith et al. 2000, and Busse et al. 2001 observed that fungicides such as captan, benomyl and glyphosate had negative impact on fungal population size. Shukla, A.K. et al., 1987, inferred that the adverse effect of fungicides was severe and prolonged in case of rhizospheric fungi. Population of dominant fungi like Penicillium chrysogenum was drastically reduced in the fungicide treated set. The effect of fungicides is evident from the extinction of species like A.oryzae, C.lunata, F.oxysporum, F.solani, P.aurentiogriseum and T.harzianum. Majid Mohiuddin and Mazharuddin Khan Mohammed 2013 results clearly indicate that in initial days application of Fungicide - Carbendazim, drastically reduced the number of fungi, in treated soil compared with that of untreated (Control) soil. During the present investigation Carbendazim had lesser effect on fungi compared to COC and Mancozeb. Results were similar with that of Abhishek Walia et al., 2014., which reported that increase in Mancozeb concentrations up to $100 \mathrm{ppm}$ and above decreased fungal population. Bogomolov et al. 1996 found that application of copper resulted in reduced microbial activity and function. According to Hemanth, G et al., 2016 the fungal populations in each of the five agricultural soils were significantly decreased in the presence of three different fungicides such as Carbendazim, $\mathrm{COC}$ and Commodity Mancozeb. Application of fungicide to an agricultural soil may affect the composition of the microbial communities and thus disturb the fertility of the soil. Results are similar with Shukla, A.K. 2000., where fungal and bacterial population dropped on application of fungicides in the soil. He also observed that enzyme activity was also disrupted after application of fungicides. The results are similar with earlier reports of Colinas et al., 1994 and Shukla, A.K. et al., 1987.

\section{Conclusion}

Use of fungicides for the control of soil borne diseases is costly and also produces environment and health hazards to living organisms and also adversely affects the beneficial microorganisms present in the soil. It was understood that the fungicide Mancozeb had a considerable deleterious impact on soil mycoflora. Effect of fungicide application on soil microbial spectrum was studied, and the result indicated that comparative analysis of the fungal population shown a decrease due to application of $1 / 2 \mathrm{Lt}$ and $1 \mathrm{Lt}$ applications of pesticide in the soil samples. Extinction of few of the fungal species was also observed which leads to the reduction in the fertility of the soils. It is thus concluded that in spite the importance of pesticides used in agriculture, arbitrary use of these can lead to soil degradation.

\section{References}

[1] Abdelfattah, H. M., Kader, M. A. A. and Hamida, S. 1982. Selective effect of two systemic fungicides on soil fungi. Mycopathologia 79: 93-99.

[2] Abhishek Walia, Preeti Mehta, Shiwani Guleria, Anjali Chauhan and C.K. Shirkot. 2014. Impact of Fungicide Mancozeb at Different Application Rates on Soil Microbial Populations, Soil Biological Processes, and Enzyme Activities in Soil. Hindawi Publishing Corporation Scientific World Journal Volume 2014, Article ID 702909, 9 pages.

[3] Anderson, J. P. E., Armstrong, R. A., Smith, S. N. 1981. Methods to evaluate pesticides damage to the biomass of the soil microflora. Soil Biology \& Biochemistry 13 (149), 9.

[4] Bogomolov, D. M., Chen, S. K., Parmelee, R. W., Subler, S., Edwards, C. A. 1996. An ecosystem approach to soil toxicity testing: a study of copper contamination in laboratory soil microcosms. Applied Soil Ecology 4: 95-105.

[5] Brun, L. A., Maillet, J., Richarte, J., Herrmann, P., Remy, J. C. 1998. Relationships between Extractable Copper, Soil Properties and Copper Uptake by Wild Plants in Vineyard Soils. Environmental Pollution 102:151-161.

[6] Busse, M. D., Ratcliffe, A. W., Shestak, C. J and Powers, R. F. 2001. Glyphosate toxicity and the effects of long term control on soil microbial communities. Soil Biol. Biochem. 33: 1777-1789.

[7] Chandra, S., Raizada, M and Khanna, K. K. 1982. Change in rhizosphere microflora of tomato by foliar application of streptomycin; Indian Phytopath. 35: 226231.

[8] Colinas, C., Ingham, E and Molina, R. 1994. Population response of target and non-target forest soil organisms to selected biocides. Soil Biol Biochem. 26: 41-47.

[9] Doneche, B., Suguin, G and Gayon, P. R. 1983. Mancozeb effect on soil microorganisms and its degradation in soils; Soil Sci. 135: 361-366.

[10] Dumestre, A., Sauve, S., McBride, M., Baveye, P., Berthelin, J. 1999. Copper speciation and microbial activity in long-term contaminated soils. Archives of

\section{Volume 6 Issue 1, January 2017 www.ijsr.net}




\section{International Journal of Science and Research (IJSR) \\ ISSN (Online): 2319-7064}

Index Copernicus Value (2015): 78.96 | Impact Factor (2015): 6.391

Environmental Contamination and Toxicology 36: 124131.

[11]Elain, I. 2001. Tropical Soil Biology and Fertility (1st eds.) Walinford Publisher, UK. pp. 152.

[12] Hemanth, G., Ratna Kumar, P. K., Shiny Niharika, P. and Samuel. K .kolli. 2016. Fungicides Effect on Soil Micro Flora in Tekkali Mandal, Srikakulam (Dist.). International Journal of Research and Development in Pharmacy and Life Sciences. 5(4): 2245-2250.

[13] Kuthubutheen, A. J. 1979. Effect of fungicide on soil fungal populations; Soil Biol. Biochem. 11: 297-303.

[14]Liao, J. P., Lin, X. G., Cao, Z. H., Shi, Y. Q., Wong, M. H. 2003. Interactions between arbuscular mycorrhizae and heavy metals under sand culture experiment. Chemosphere 50: 847-853.

[15] Maboeta, M. S., Reinecke, S. A., Reinecke, A. J. 2003. Linking lysosomal biomarker and population responses in a field population of Aporrectodea caliginosa (Oligochaete) exposed to the fungicide copper oxychloride. Ecotoxicology and Environmental Safety. 56, 411-418.

[16] Majid Mohiuddin, Mazharuddin Khan Mohammed 2013. Influence of fungicide (Carbendazim) and herbicides (2, 4-D and Metribuzin) on non-target beneficial soil microorganisms of Rhizospheric Soil of Tomato Crop. IOSR Journal Of Environmental Science, Toxicology And Food Technology (IOSR-JESTFT). 5(1): 47-50.

[17] Mariusz Cycon and Zofia Piotrowska-Seget. 2007. Effect of Selected Pesticides on Soil Microflora Involved in Organic Matter and Nitrogen Transforations: Pot Experiment. 55(2): 207-220.

[18] Martınez-Toledo, M. V., Salmeron, V., Rodelas, B., Pozo, C. and Gonzalez-Lopez, J. 1998. Effects of the fungicide Captan on some functional groups of soil Microflora. Applied Soil Ecology 7: 245-255.

[19] Mishra, P. C., 2001. Soil Population and Organisms. Ashish Publishing House, Punjabi Bagh, New Delhi, pp. 3-34.

[20] Pankhurst, C. E., Doube, B. M., Gupta, V. V. S. R. 1997. Biological Indicators of Soil, edn.

[21] Pozo, C., Rodelas, B., Salmeron, Y., Martınez-Toledo, M. Y., Vela, G. R., and Gonzalez-Lopez, J. 1994. Effects of fungicides maneb and mancozeb on soil microbial populations. Toxicol. Environ. Chem. 43: 123-132.

[22] Shukla, A. K. 2000. Impact of fungicides on soil microbial population and enzyme activities. Acta Botanica Indica. 25: 85-87.

[23] Shukla, A. K., Tiwari, B. K. and Mishra, R. R. 1987. Effect of Benomyl, Copper oxychloride and Mancozeb on rhizosphere Microflora of Potato. Indian natn. Sci. Acad. B53 No. 3 pp. 273-278.

[24] Smith, M. D., Hartnett, D. C., Rice, C. W. 2000. Effects of long-term fungicide applications on microbial properties in tallgrass prairie soil. Soil Biology and Biochemistry. 32: 935-946.

[25] Srivastava, L. S. and Dayal R. 1981. Studies on rhizosphere microflora of Abelmoschus esculentus Effect of fungicidal spray on rhizophere and rhizoplane microflora; Indian Phytopath. 34: 426-429.

[26] Srivastava, V. B., Tewari, R. P. and Mishra, R. R. 1970. Investigation on the rhizosphere microflora; Acta Phytopath. 34: 426-429.

[27] Tortensson, L. 1979. Effect of pesticides on soil organisms 2. Microorganisms; Stat Naturvardserk. PM. 1208: $1-52$.

[28] Tortensson, L. and Wessen, B. 1984. Interaction between the fungicide benomyl and soil microorganisms; Soil Biol. Biochem. 16: 445-452.

[29] Wainwright, M. 1977. Effect of fungicides on the microbiology and Biochemistry of soils a review. $Z$ Planzenernacher Bodenkd. 140: 587-603.

[30] Wainwright, M. 1978. A review on the effect of pesticides on microbial activity in soils; J. Soil Sci. 29: 287-298.

[31] Wainwright, M. and Pugh, G. J. F. 1973. The effect of three fungicides on nitrification and ammonification in soil; soil Biol. Biochem. 5: 577-584.

[32] Wainwright, M. and Pugh, G. J. F. 1974. The effect of fungicides on certain chemical and microbial properties of soil; Soil Biol. Biochem. 6: 263-267.

[33] Wainwright, M. and Pugh, G. J. F. 1975 a. Change in the free amino-acid content of soil following fungicide treatment; Soil Biol. Biochem. 7: 1-4.

[34] Waksman, S. A. 1922. A method of counting the number of fungi in the soil.J. Bact. 7: 339-341.

Table 1: Fungi Isolated From Soil Samples Not Treated With Pesticides

\begin{tabular}{|c|l|c|c|c|c|c|c|c|c|c|}
\hline S.No & Name of the Organism & Rice & Black gram & Ground nut & Mean \pm SE & TOTAL & $\%$ & VSD & PSD & VPSD \\
\hline 1 & Aspergillus flavus & 14 & 15 & 14 & $14.33 \pm 0.33$ & 43 & 15.24 & 0.33 & 0.47 & 0.22 \\
\hline 2 & Aspergillus niger & 19 & 17 & 19 & $18.33 \pm 0.66$ & 55 & 19.5 & 1.33 & 0.94 & 0.88 \\
\hline 3 & Aspergillus oryzae & 7 & 4 & 6 & $5.66 \pm 0.88$ & 17 & 6.02 & 2.33 & 1.24 & 1.55 \\
\hline 4 & Curvularia lunata & 6 & 5 & 6 & $5.66 \pm 0.33$ & 17 & 6.02 & 0.33 & 0.47 & 0.22 \\
\hline 5 & Fusarium oxysporum & 4 & 3 & 3 & $3.33 \pm 0.33$ & 10 & 3.54 & 0.33 & 0.47 & 0.22 \\
\hline 6 & Fusarium solani & 3 & 2 & 3 & $2.66 \pm 0.33$ & 8 & 2.83 & 0.33 & 0.47 & 0.22 \\
\hline 7 & Penicillium aurentiogriseum & 12 & 8 & 10 & $10 \pm 1.15$ & 30 & 10.63 & 4.00 & 1.63 & 2.66 \\
\hline 8 & Pencillium chrysogenum & 16 & 16 & 14 & $15.33 \pm 0.66$ & 46 & 16.31 & 1.33 & 0.94 & 0.88 \\
\hline 9 & Penicillium frequentans & 10 & 7 & 12 & $9.66 \pm 1.45$ & 29 & 10.28 & 6.33 & 2.05 & 4.22 \\
\hline 10 & Rhizopus stolonifer & 7 & 6 & 7 & $6.66 \pm 0.33$ & 20 & 7.09 & 0.33 & 0.47 & 0.22 \\
\hline 11 & Trichoderma harzianum & 3 & 2 & 2 & $2.33 \pm 0.33$ & 7 & 2.48 & 0.33 & 0.47 & 0.22 \\
\hline & & 101 & 85 & 96 & & 282 & & & & \\
\hline & & 9.18 & 7.72 & 8.72 & & & & & & \\
\hline
\end{tabular}

SE: Standard Error

VSD: Variance Standard Deviation

PSD: Population Standard Deviation

\section{Volume 6 Issue 1, January 2017 www.ijsr.net}




\section{International Journal of Science and Research (IJSR) ISSN (Online): 2319-7064 \\ Index Copernicus Value (2015): 78.96 | Impact Factor (2015): 6.391}

VPSD: Variance Population Standard Deviation

Table 2: ANNOVA for Fungi isolated from soil not treated with pesticides

\begin{tabular}{|c|c|c|c|c|c|c|}
\hline $\begin{array}{c}\text { Source of } \\
\text { Variation }\end{array}$ & $\begin{array}{c}\text { Sum of Square } \\
\text { Values (SS) }\end{array}$ & $\begin{array}{c}\text { Degree of } \\
\text { Freedom (d.f) }\end{array}$ & $\begin{array}{c}\text { Mean Sum of } \\
\text { Squares (MS) }\end{array}$ & $F$ & P-value & F crit \\
\hline SSB & 12.1818 & 2 & 6.090909 & 0.19861 & $0.820934^{@}$ & 3.31583 \\
\hline SSW & 920 & 30 & 30.66667 & & & \\
\hline SST & 932.1818 & 32 & & & & \\
\hline
\end{tabular}

$@=$ probability level is not significant.

Table 3: Biodiversity Indices of Fungal Species in Narasannapeta in 3 different crop soils not treated with pesticides

\begin{tabular}{|l|c|c|c|}
\hline \multicolumn{1}{|c|}{ Index } & Rice & Black Gram & Ground Nut \\
\hline Simpson Index & 0.1113 & 0.1249 & 0.1145 \\
\hline Dominance Index & 0.8887 & 0.8751 & 0.8855 \\
\hline Shannon Index & 3.227 & 3.12 & 3.192 \\
\hline Menhinick Index & 1.095 & 1.193 & 1.123 \\
\hline Berger-Parker Dominance Index & 0.1881 & 0.2 & 0.1979 \\
\hline Equitability Index & 0.9327 & 0.9018 & 0.9227 \\
\hline Margalef Richness Index & 2.167 & 2.251 & 2.191 \\
\hline
\end{tabular}

Table 4: Fungi Isolates From the Soil Samples Treated With 1/2 Lt Fungicides

\begin{tabular}{|c|c|c|c|c|c|c|c|c|c|c|c|c|c|}
\hline \multirow[b]{2}{*}{ S.No } & \multirow[b]{2}{*}{ Name of the Organism } & \multicolumn{4}{|c|}{ CARBENDAZIM } & \multicolumn{4}{|c|}{$\mathrm{COC}$} & \multicolumn{4}{|c|}{ MANCOZEB } \\
\hline & & Rice & $\begin{array}{l}\text { Black } \\
\text { gram }\end{array}$ & $\begin{array}{c}\text { Ground } \\
\text { nut }\end{array}$ & Mean \pm SE & Rice & $\begin{array}{l}\text { Black } \\
\text { gram }\end{array}$ & $\begin{array}{c}\text { Ground } \\
\text { nut }\end{array}$ & $\begin{array}{c}\text { Mean } \pm \\
\text { SE }\end{array}$ & Rice & $\begin{array}{l}\text { Black } \\
\text { gram }\end{array}$ & $\begin{array}{c}\text { Ground } \\
\text { nut }\end{array}$ & $\begin{array}{c}\text { Mean } \pm \\
\text { SE }\end{array}$ \\
\hline 1 & Aspergillus flavus & 9 & 8 & 7 & $8 \pm 0.57$ & 9 & 7 & 7 & $7.66 \pm 0.66$ & 7 & 8 & 7 & $7.33 \pm 0.33$ \\
\hline 2 & Aspergillus niger & 10 & 10 & 11 & $10.33 \pm 0.33$ & 11 & 10 & 9 & $10 \pm 0.57$ & 10 & 9 & 9 & $9.33 \pm 0.33$ \\
\hline 3 & Aspergillus oryzae & 4 & 2 & 3 & $3 \pm 0.57$ & 4 & 2 & 4 & $3.33 \pm 0.66$ & 4 & 2 & 3 & $3 \pm 0.57$ \\
\hline 4 & Curvularia lunata & 3 & 4 & 3 & $3.33 \pm 0.33$ & 3 & 3 & 3 & $3 \pm 0$ & 2 & 2 & 3 & $2.33 \pm 0.33$ \\
\hline 5 & Fusarium oxysporum & 2 & 1 & 2 & $1.66 \pm 0.33$ & 2 & 1 & 1 & $1.33 \pm 0.33$ & 2 & 0 & 2 & $1.33 \pm 0.66$ \\
\hline 6 & Fusarium solani & 2 & 2 & 1 & $1.66 \pm 0.33$ & 2 & 1 & 2 & $1.66 \pm 0.33$ & 2 & 1 & 2 & $1.66 \pm 0.33$ \\
\hline 7 & Penicillium aurentiogriseum & 8 & 5 & 5 & $6 \pm 1.00$ & 8 & 4 & 5 & $5.66 \pm 1.20$ & 6 & 3 & 4 & $4.33 \pm 0.88$ \\
\hline 8 & Pencillium chrysogenum & 10 & 7 & 8 & $8.33 \pm 0.88$ & 10 & 8 & 7 & $8.33 \pm 0.88$ & 8 & 8 & 7 & $7.66 \pm 0.33$ \\
\hline 9 & Pencillium frequentans & 7 & 5 & 7 & $6.33 \pm 0.66$ & 6 & 6 & 7 & $6.33 \pm 0.33$ & 5 & 4 & 6 & $5 \pm 0.57$ \\
\hline 10 & Rhizopus stolonifer & 5 & 3 & 4 & $4 \pm 0.57$ & 5 & 4 & 4 & $4.33 \pm 0.33$ & 4 & 3 & 3 & $3.33 \pm 0.33$ \\
\hline 11 & Trichoderma harzianum & 2 & 2 & 1 & $1.66 \pm 0.33$ & 2 & 1 & 1 & $1.33 \pm 0.33$ & 2 & 0 & 0 & $0.66 \pm 0.66$ \\
\hline & & 62 & 49 & 52 & & 62 & 47 & 50 & & 52 & 40 & 46 & \\
\hline & & 5.63 & 4.45 & 4.72 & & 5.63 & 4.27 & 4.54 & & 4.72 & 3.63 & 4.18 & \\
\hline
\end{tabular}

SE: Standard Error

Table 5: ANNOVA for Fungi isolated from soil of 3 crops treated with $1 / 2$ LT Carbendazim

\begin{tabular}{|c|l|l|l|l|l|l|}
\hline Source of Variation & Sum of Square Values (SS) & Degree of Freedom (d.f) & Mean Sum of Squares (MS) & $F$ & $P$-value & $F$ crit \\
\hline
\end{tabular}

\begin{tabular}{|c|c|c|c|c|c|c|}
\hline SSB & 8.424242 & 2 & 4.212121 & 0.433562 & $0.652193^{\Theta}$ & 3.31583 \\
\hline SSW & 291.4545 & 30 & 9.715152 & & & \\
\hline SST & 299.8788 & 32 & & & & \\
\hline
\end{tabular}

$@=$ probability level is not significant.

Table 6: ANNOVA for Fungi isolated from soil of 3 crops treated with $1 / 2$ LT COC

\begin{tabular}{|c|c|c|c|c|c|c|}
\hline $\begin{array}{c}\text { Source of } \\
\text { Variation }\end{array}$ & $\begin{array}{c}\text { Sum of Square } \\
\text { Values (SS) }\end{array}$ & $\begin{array}{c}\text { Degree of } \\
\text { Freedom (d.f) }\end{array}$ & $\begin{array}{c}\text { Mean Sum of } \\
\text { Squares (MS) }\end{array}$ & $F$ & P-value & F crit \\
\hline SSB & 11.45455 & 2 & 5.727273 & 0.606158 & $0.551987^{\Theta}$ & 3.31583 \\
\hline SSW & 283.4545 & 30 & 9.448485 & & & \\
\hline SST & 294.9091 & 32 & & & & \\
\hline
\end{tabular}

$@=$ probability level is not significant.

Table 7: ANNOVA for Fungi isolated from soil of 3 crops treated with $1 / 2$ LT Mancozeb

\begin{tabular}{|c|c|c|c|c|c|c|}
\hline $\begin{array}{c}\text { Source of } \\
\text { Variation }\end{array}$ & $\begin{array}{c}\text { Sum of Square } \\
\text { Values (SS) }\end{array}$ & $\begin{array}{c}\text { Degree of } \\
\text { Freedom (d.f) }\end{array}$ & $\begin{array}{c}\text { Mean Sum of } \\
\text { Squares (MS) }\end{array}$ & $F$ & P-value & F crit \\
\hline SSB & 6.545455 & 2 & 3.272727 & 0.382979 & $0.685113^{@}$ & 3.31583 \\
\hline SSW & 256.3636 & 30 & 8.545455 & & & \\
\hline SST & 262.9091 & 32 & & & & \\
\hline
\end{tabular}

$@=$ probability level is not significant.

\section{Volume 6 Issue 1, January 2017 www.ijsr.net}

Licensed Under Creative Commons Attribution CC BY 


\section{International Journal of Science and Research (IJSR) \\ ISSN (Online): 2319-7064 \\ Index Copernicus Value (2015): 78.96 | Impact Factor (2015): 6.391}

Table 8: Fungi Isolates From The Soil Samples Treated With 1 Lt Fungicides

\begin{tabular}{|c|c|c|c|c|c|c|c|c|c|c|c|c|c|}
\hline \multirow{2}{*}{$\begin{array}{l}\text { S. } \\
\text { No }\end{array}$} & \multirow[b]{2}{*}{ Name of the Organism } & \multicolumn{4}{|c|}{ CARBENDZIM } & \multicolumn{4}{|c|}{$\mathrm{COC}$} & \multicolumn{4}{|c|}{ MANCOZEB } \\
\hline & & Rice & $\begin{array}{l}\text { Black } \\
\text { gram }\end{array}$ & $\begin{array}{c}\text { Ground } \\
\text { nut }\end{array}$ & Mean \pm SE & Rice & $\begin{array}{l}\text { Black } \\
\text { gram }\end{array}$ & $\begin{array}{c}\text { Ground } \\
\text { nut }\end{array}$ & Mean \pm SE & Rice & $\begin{array}{l}\begin{array}{c}\text { Black } \\
\text { gram }\end{array} \\
\end{array}$ & $\begin{array}{c}\text { Ground } \\
\text { nut }\end{array}$ & Mean \pm SE \\
\hline 1 & Aspergillus flavus & 6 & 4 & 4 & $4.66 \pm 0.66$ & 5 & 3 & 4 & $4 \pm 0.57$ & 3 & 4 & 3 & $3.3 \pm 0.33$ \\
\hline 2 & Aspergillus niger & 8 & 7 & 6 & $7 \pm 0.57$ & 9 & 7 & 5 & $7 \pm 1.15$ & 6 & 5 & 4 & $5.00 \pm 0.57$ \\
\hline 3 & Aspergillus oryzae & 2 & 1 & 1 & $1.33 \pm 0.33$ & 2 & 0 & 2 & $1.33 \pm 0.66$ & 1 & 0 & 1 & $0.66 \pm 0.33$ \\
\hline 4 & Curvularia lunata & 1 & 2 & 1 & $1.33 \pm 0.33$ & 2 & 1 & 0 & $1 \pm 0.57$ & 1 & 0 & 0 & $0.33 \pm 0.33$ \\
\hline 5 & Fusarium oxysporum & 1 & 0 & 1 & $0.66 \pm 0.33$ & 0 & 0 & 1 & $0.33 \pm 0.33$ & 0 & 0 & 1 & $0.33 \pm 0.33$ \\
\hline 6 & Fusarium solani & 0 & 1 & 0 & $0.33 \pm 0.33$ & 0 & 0 & 1 & $0.33 \pm 0.33$ & 0 & 0 & 1 & $0.33 \pm 0.33$ \\
\hline 7 & Penicillium aurentiogriseum & 3 & 2 & 3 & $2.66 \pm 0.33$ & 2 & 2 & 3 & $2.33 \pm 0.33$ & 2 & 0 & 2 & $1.33 \pm 0.66$ \\
\hline 8 & Pencillium chrysogenum & 6 & 5 & 4 & $5 \pm 0.57$ & 5 & 5 & 4 & $4.66 \pm 0.33$ & 4 & 4 & 3 & $3.66 \pm 0.33$ \\
\hline 9 & Pencillium frequentans & 4 & 3 & 4 & $3.66 \pm 0.33$ & 4 & 3 & 3 & $3.33 \pm 0.33$ & 2 & 2 & 3 & $2.33 \pm 0.33$ \\
\hline 10 & Rhizopus stolonifer & 3 & 1 & 2 & $2 \pm 0.57$ & 2 & 2 & 2 & $2 \pm 0$ & 1 & 1 & 1 & $1 \pm 0$ \\
\hline 11 & Trichoderma harzianum & 1 & 1 & 0 & $0.66 \pm 0.33$ & 0 & 0 & 0 & $0 \pm 0$ & 0 & 0 & 0 & $0 \pm 0$ \\
\hline & & 35 & 27 & 26 & & 31 & 23 & 25 & & 20 & 16 & 19 & \\
\hline & & 3.18 & 2.45 & 2.36 & & 2.81 & 2.09 & 2.27 & & 1.81 & 1.45 & 1.72 & \\
\hline
\end{tabular}

SE: Standard Error

Table 9: ANNOVA for Fungi isolated from soil of 3 crops treated with 1 LT Carbendazim

\begin{tabular}{|l|l|l|l|l|l|l|}
\hline Source of Variation & Sum of Square Values (SS) & Degree of Freedom (d.f) & Mean Sum of Squares (MS) & $F$ & $P$-value & $F$ crit \\
\hline
\end{tabular}

\begin{tabular}{|c|c|c|c|c|c|c|}
\hline SSB & 4.424242 & 2 & 2.212121 & 0.44566 & $0.644569^{@}$ & 3.31583 \\
\hline SSW & 148.9091 & 30 & 4.963636 & & & \\
\hline SST & 153.3333 & 32 & & & & \\
\hline
\end{tabular}

$@=$ probability level is not significant.

Table 10: ANNOVA for Fungi isolated from soil of 3 crops treated with 1 LT COC

\begin{tabular}{|c|c|c|c|c|c|c|}
\hline $\begin{array}{c}\text { Source of } \\
\text { Variation }\end{array}$ & $\begin{array}{c}\text { Sum of Square } \\
\text { Values (SS) }\end{array}$ & $\begin{array}{c}\text { Degree of } \\
\text { Freedom (d.f) }\end{array}$ & $\begin{array}{c}\text { Mean Sum of } \\
\text { Squares (MS) }\end{array}$ & F & P-value & F crit \\
\hline SSB & 3.151515 & 2 & 1.57575 & 0.3016 & $0.741833 @$ & 3.31583 \\
\hline SSW & 156.7273 & 30 & 5.224242 & & & \\
\hline SST & 159.8788 & 32 & & & & \\
\hline
\end{tabular}

$@=$ probability level is not significant.

Table 11: ANNOVA for Fungi isolated from soil of 3 crops treated with 1 LT Mancozeb

\begin{tabular}{|c|c|c|c|c|c|c|}
\hline $\begin{array}{c}\text { Source of } \\
\text { Variation }\end{array}$ & $\begin{array}{c}\text { Sum of Square } \\
\text { Values (SS) }\end{array}$ & $\begin{array}{c}\text { Degree of } \\
\text { Freedom (d.f) }\end{array}$ & $\begin{array}{c}\text { Mean Sum of } \\
\text { Squares (MS) }\end{array}$ & F & P-value & F crit \\
\hline SSB & 0.787879 & 2 & 0.393939 & 0.1277 & $0.880592 @$ & 3.31583 \\
\hline SSW & 92.54545 & 30 & 3.084848 & & & \\
\hline SST & 93.33333 & 32 & & & & \\
\hline
\end{tabular}

$@=$ probability level is not significant.

Table 12: Biodiversity Indices of Fungal Species in Narasannapeta in 3 different crop soils treated with different types of pesticides

\begin{tabular}{|c|c|c|c|c|c|c|c|c|c|c|}
\hline \multicolumn{4}{|c|}{ Index } & $\begin{array}{c}\text { Simpson } \\
\text { Index }\end{array}$ & $\begin{array}{c}\text { Dominance } \\
\text { Index }\end{array}$ & $\begin{array}{l}\text { Shannon } \\
\text { Index }\end{array}$ & $\begin{array}{l}\text { Menhinick } \\
\text { Index }\end{array}$ & $\begin{array}{c}\text { Berger-Parker } \\
\text { Dominance Index }\end{array}$ & $\begin{array}{l}\text { Equita- } \\
\text { bility } \\
\text { Index }\end{array}$ & $\begin{array}{l}\text { Margalef } \\
\text { Richness } \\
\text { Index }\end{array}$ \\
\hline \multirow{6}{*}{ Rice } & \multirow{6}{*}{ Fungicides } & \multirow{2}{*}{ Carbendazim } & $1 / 2 \mathrm{LT}$ & 0.1042 & 0.8958 & 3.229 & 1.397 & 0.1613 & 0.9333 & 2.423 \\
\hline & & & $1 \mathrm{LT}$ & 0.1193 & 0.8807 & 3.00 & 1.69 & 0.2286 & 0.9031 & 2.531 \\
\hline & & \multirow{2}{*}{$\mathrm{COC}$} & $1 / 2 \mathrm{LT}$ & 0.1063 & 0.8937 & 3.217 & 1.397 & 0.1774 & 0.9301 & 2.423 \\
\hline & & & $1 \mathrm{LT}$ & 0.1681 & 0.8319 & 2.616 & 1.54 & 0.3333 & 0.872 & 2.124 \\
\hline & & \multirow{2}{*}{ Mancozeb } & $1 / 2 \mathrm{LT}$ & 0.1018 & 0.8982 & 3.239 & 1.525 & 0.1923 & 0.9363 & 2.531 \\
\hline & & & $1 \mathrm{LT}$ & 0.1462 & 0.8538 & 2.655 & 1.835 & 0.3158 & 0.885 & 2.377 \\
\hline \multirow{6}{*}{$\begin{array}{l}\text { Black } \\
\text { Gram }\end{array}$} & \multirow{6}{*}{ Fungicides } & \multirow{2}{*}{ Carbendazim } & $1 / 2 \mathrm{LT}$ & 0.1071 & 0.8929 & 3.189 & 1.571 & 0.2041 & 0.9219 & 2.569 \\
\hline & & & $1 \mathrm{LT}$ & 0.1197 & 0.8803 & 2.977 & 1.925 & 0.2593 & 0.896 & 2.731 \\
\hline & & \multirow{2}{*}{$\mathrm{COC}$} & $1 / 2 \mathrm{LT}$ & 0.1156 & 0.8844 & 3.105 & 1.605 & 0.2128 & 0.8975 & 2.597 \\
\hline & & & $1 \mathrm{LT}$ & 0.2083 & 0.7917 & 2.35 & 1.75 & 0.4375 & 0.8369 & 2.164 \\
\hline & & \multirow{2}{*}{ Mancozeb } & $1 / 2 \mathrm{LT}$ & 0.1465 & 0.8535 & 2.793 & 1.46 & 0.2368 & 0.8811 & 2.199 \\
\hline & & & $1 \mathrm{LT}$ & 0.2424 & 0.7576 & 1.951 & 1.443 & 0.4167 & 0.8402 & 1.61 \\
\hline \multirow{6}{*}{$\begin{array}{l}\text { Ground } \\
\text { Nut }\end{array}$} & \multirow{6}{*}{ Fungicides } & \multirow{2}{*}{ Carbendazim } & $1 / 2 \mathrm{LT}$ & 0.1116 & 0.8884 & 3.153 & 1.525 & 0.2115 & 0.9114 & 2.531 \\
\hline & & & $1 \mathrm{LT}$ & 0.12 & 0.88 & 2.873 & 1.8 & 0.24 & 0.9064 & 2.485 \\
\hline & & \multirow{2}{*}{$\mathrm{COC}$} & $1 / 2 \mathrm{LT}$ & 0.102 & 0.898 & 3.207 & 1.556 & 0.18 & 0.927 & 2.556 \\
\hline & & & $1 \mathrm{LT}$ & 0.1051 & 0.8949 & 2.955 & 1.837 & 0.2083 & 0.9322 & 2.517 \\
\hline & & \multirow{2}{*}{ Mancozeb } & $1 / 2 \mathrm{LT}$ & \begin{tabular}{|l|}
0.1063 \\
\end{tabular} & 0.8937 & 3.141 & 1.474 & 0.1957 & 0.9455 & 2.351 \\
\hline & & & $1 \mathrm{LT}$ & 0.09357 & 0.9064 & 2.971 & 2.065 & 0.2105 & 0.9372 & 2.717 \\
\hline
\end{tabular}

Volume 6 Issue 1, January 2017

www.ijsr.net

Licensed Under Creative Commons Attribution CC BY 
International Journal of Science and Research (IJSR)

ISSN (Online): 2319-7064

Index Copernicus Value (2015): 78.96 | Impact Factor (2015): 6.391

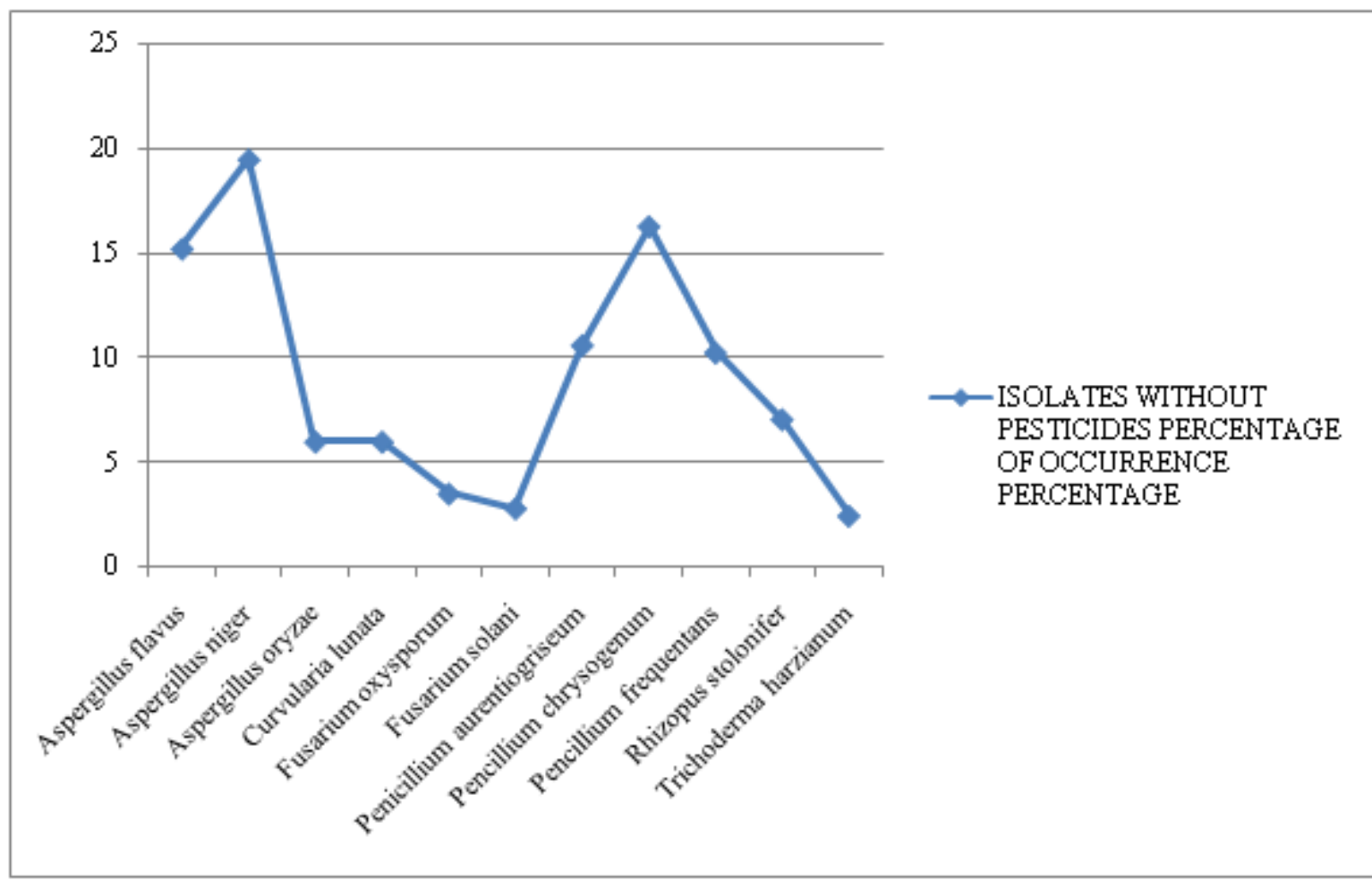

Figure 1: Percentage of Occurrence of Fungal Colonies from Soils that were not treated with Pesticides

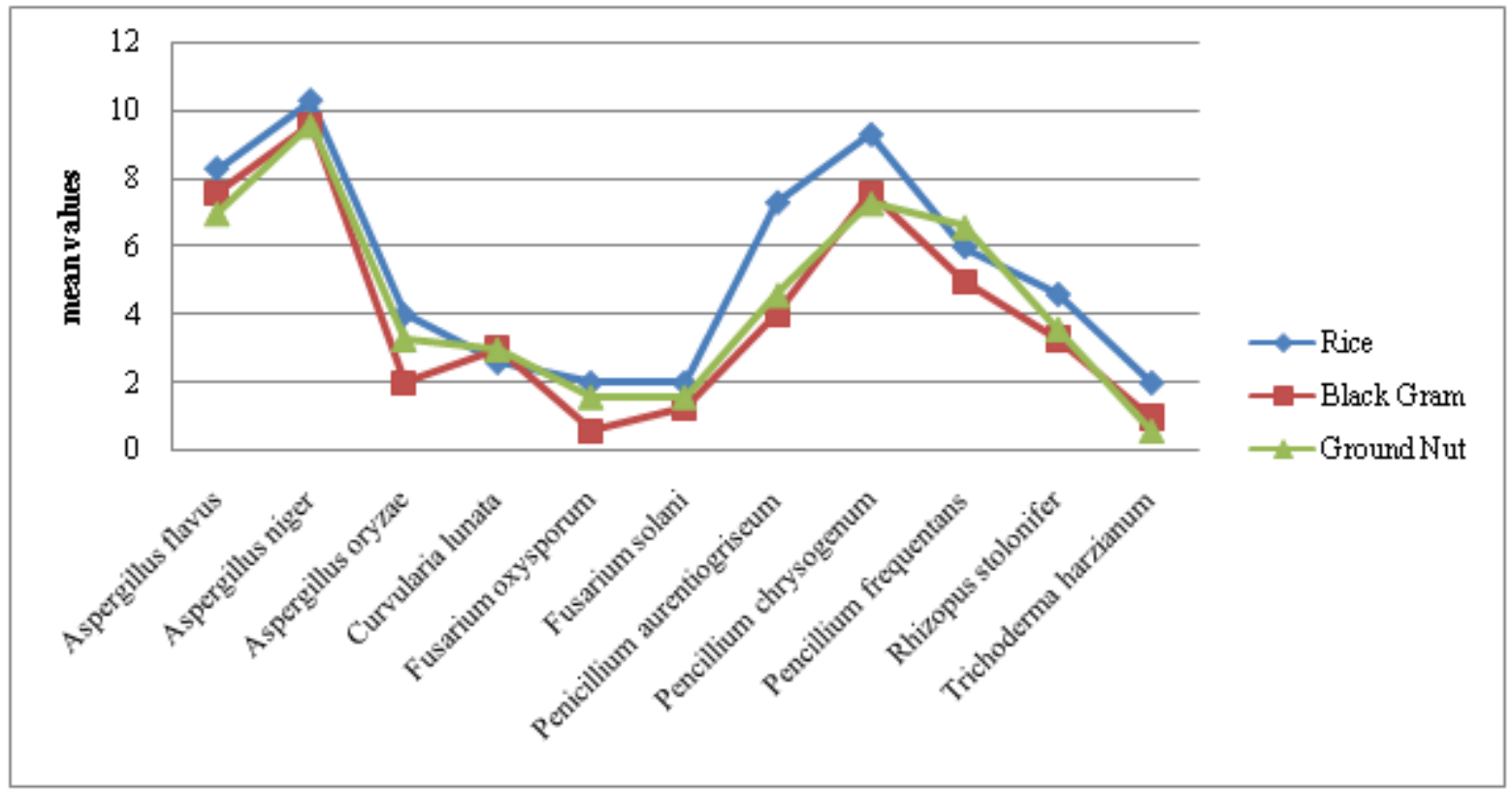

Figure 2: Variation of Mean Values of Fungal Isolates of 3 Crop Fields According to Soil Treatment with $1 / 2$ LT Fungicides

Volume 6 Issue 1, January 2017

www.ijsr.net

Licensed Under Creative Commons Attribution CC BY 
International Journal of Science and Research (IJSR)

ISSN (Online): 2319-7064

Index Copernicus Value (2015): 78.96 | Impact Factor (2015): 6.391

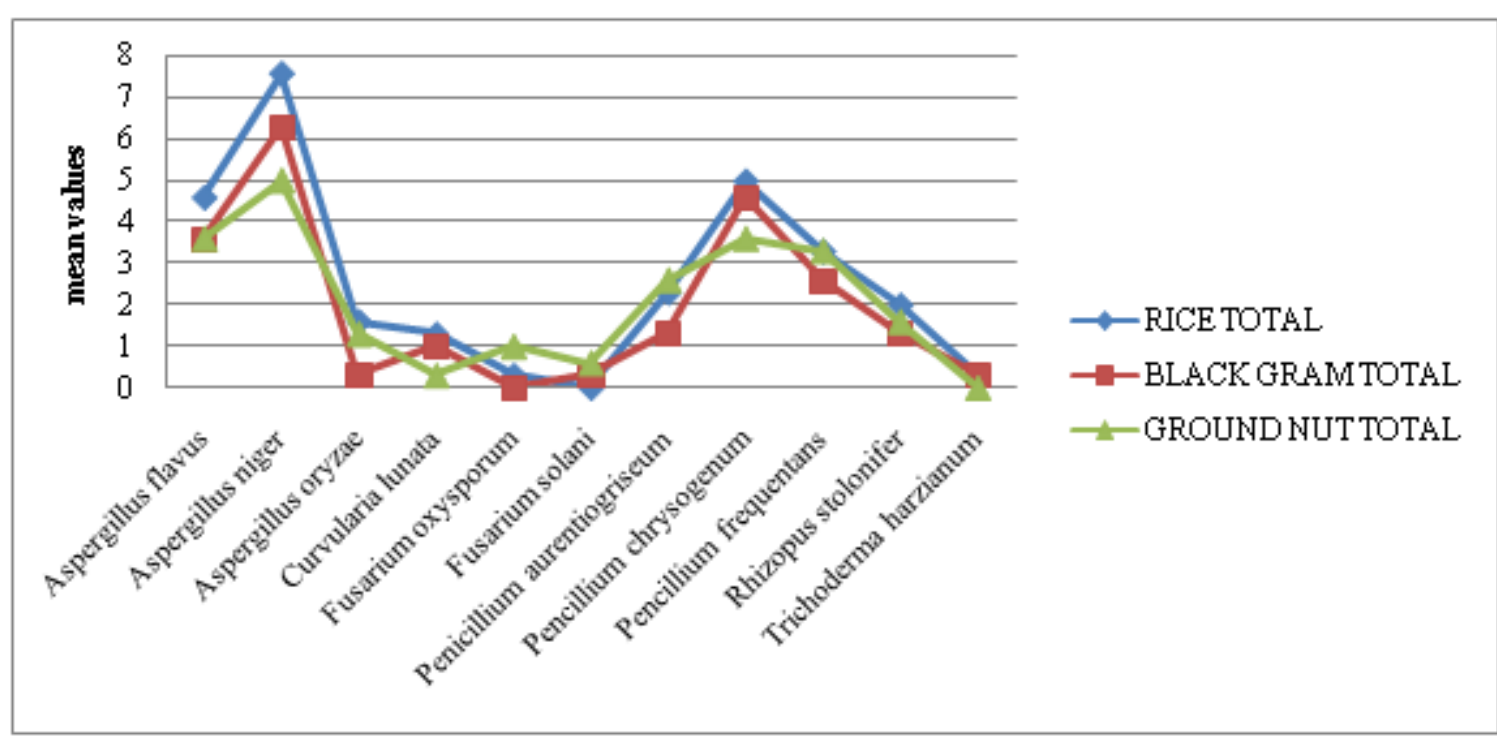

Figure 3: Variation of Mean Values of Fungal Isolates of 3 Crop Fields According to Soil Treatment with 1 LT Fungicides

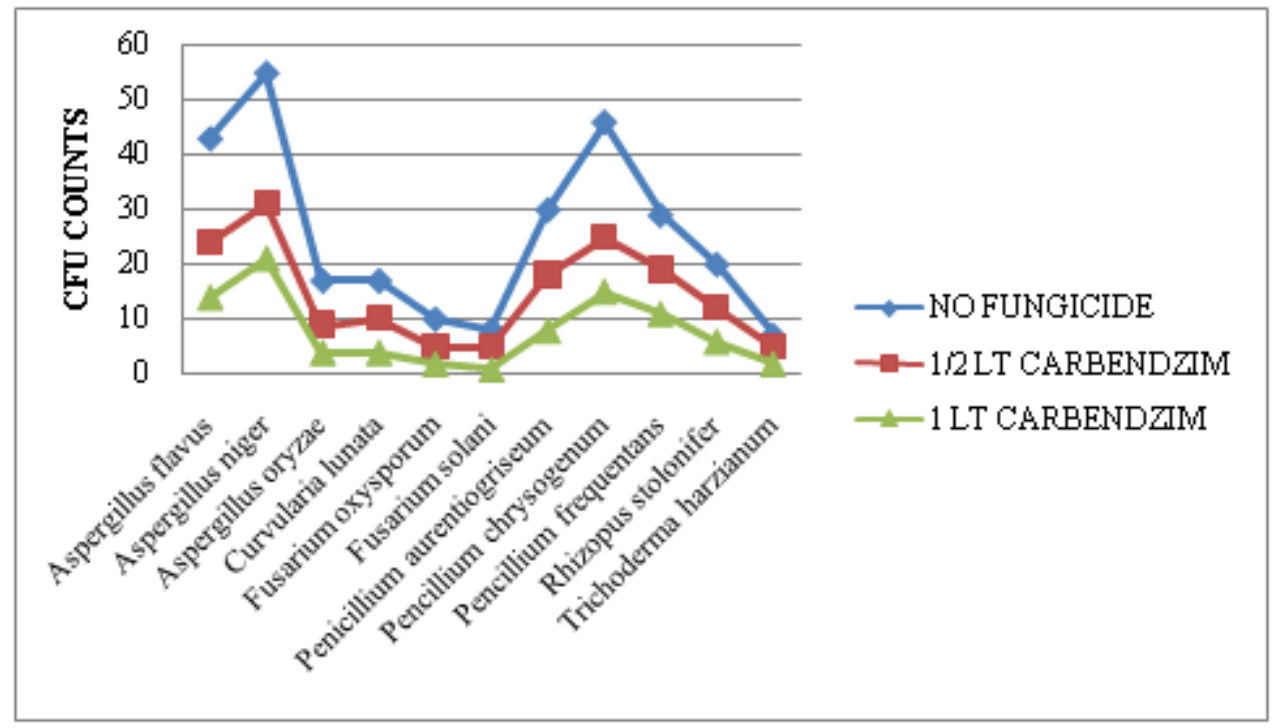

Figure 4: Frequencies of Fungal Colonies isolated from Soil Samples Treated Without and With $1 / 2$ \& 1 LT Carbendazim

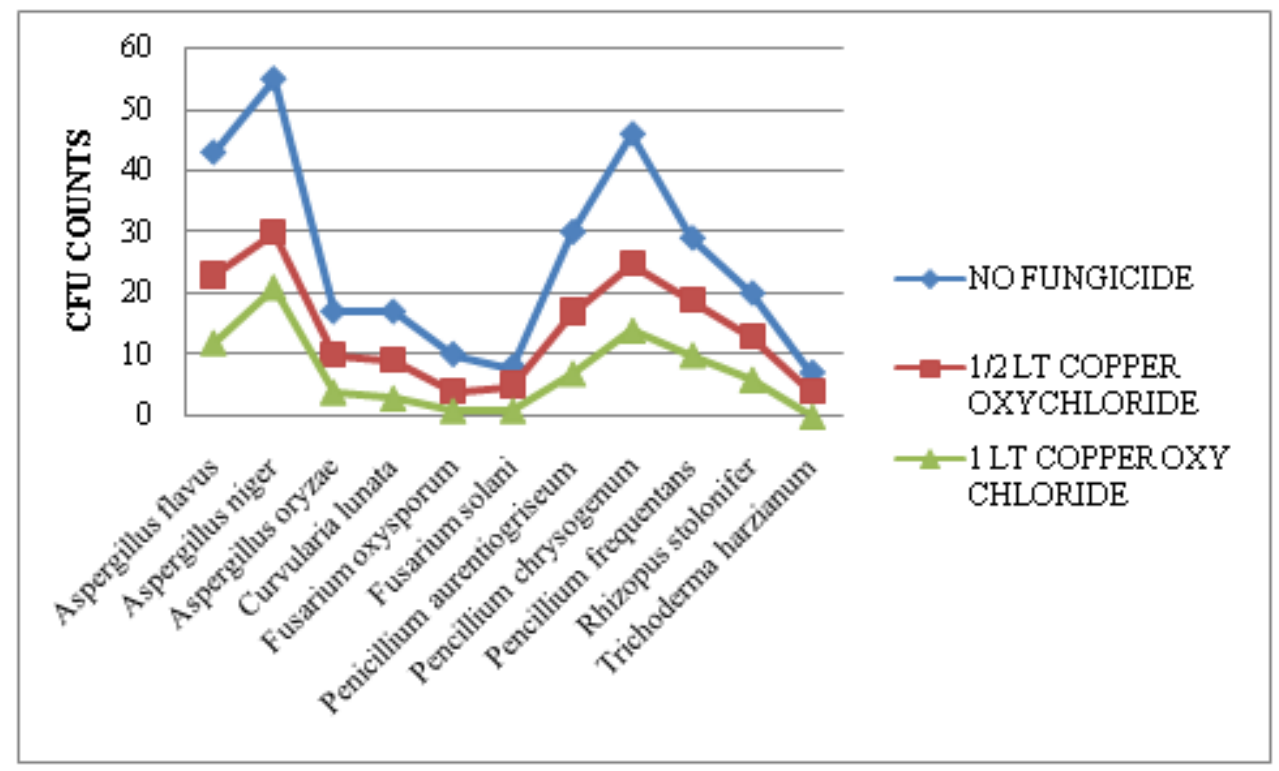

Figure 5: Frequencies of Fungal Colonies isolated from Soil Samples Treated Without and With $1 / 2 \& 1$ LT COC

\title{
Volume 6 Issue 1, January 2017
}

\author{
www.ijsr.net
}

Licensed Under Creative Commons Attribution CC BY 
International Journal of Science and Research (IJSR)

ISSN (Online): 2319-7064

Index Copernicus Value (2015): 78.96 | Impact Factor (2015): 6.391

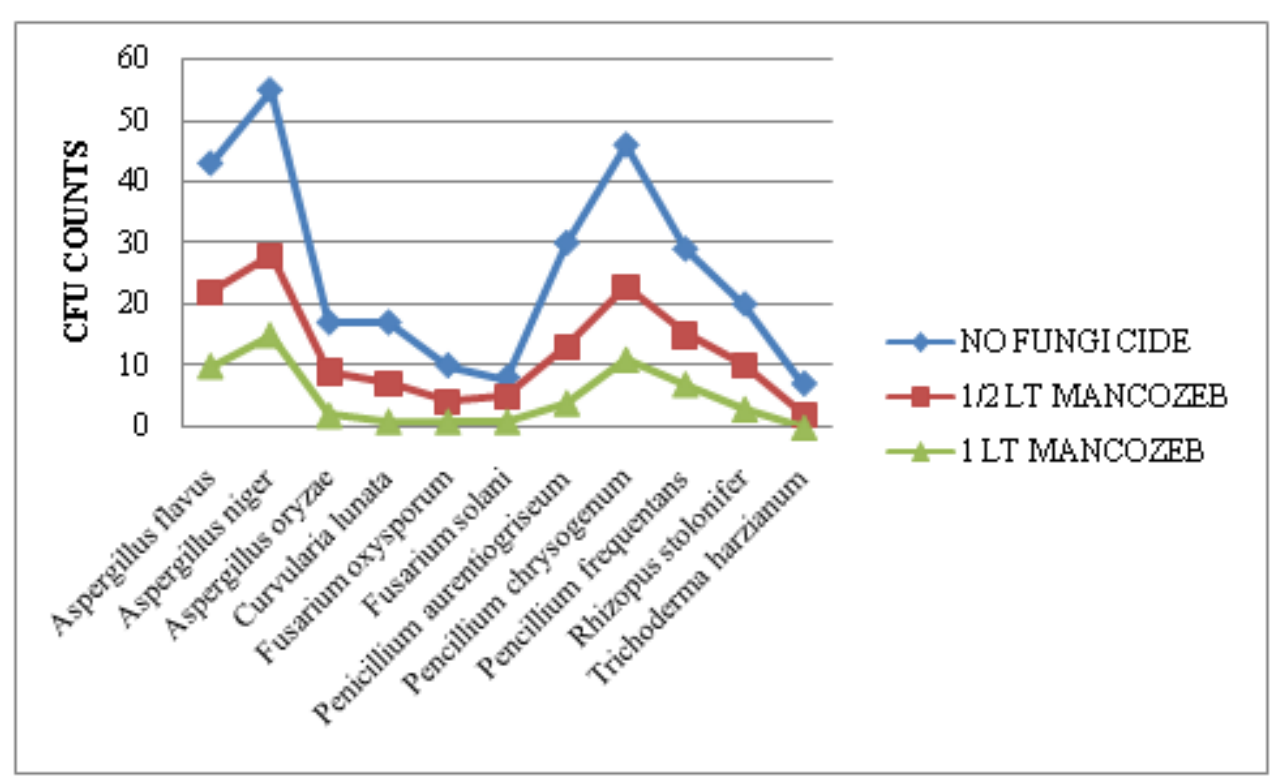

Figure 6: Frequencies of Fungal Colonies isolated from Soil Samples Treated Without and With $1 / 2$ \& 1 LT Mancozeb

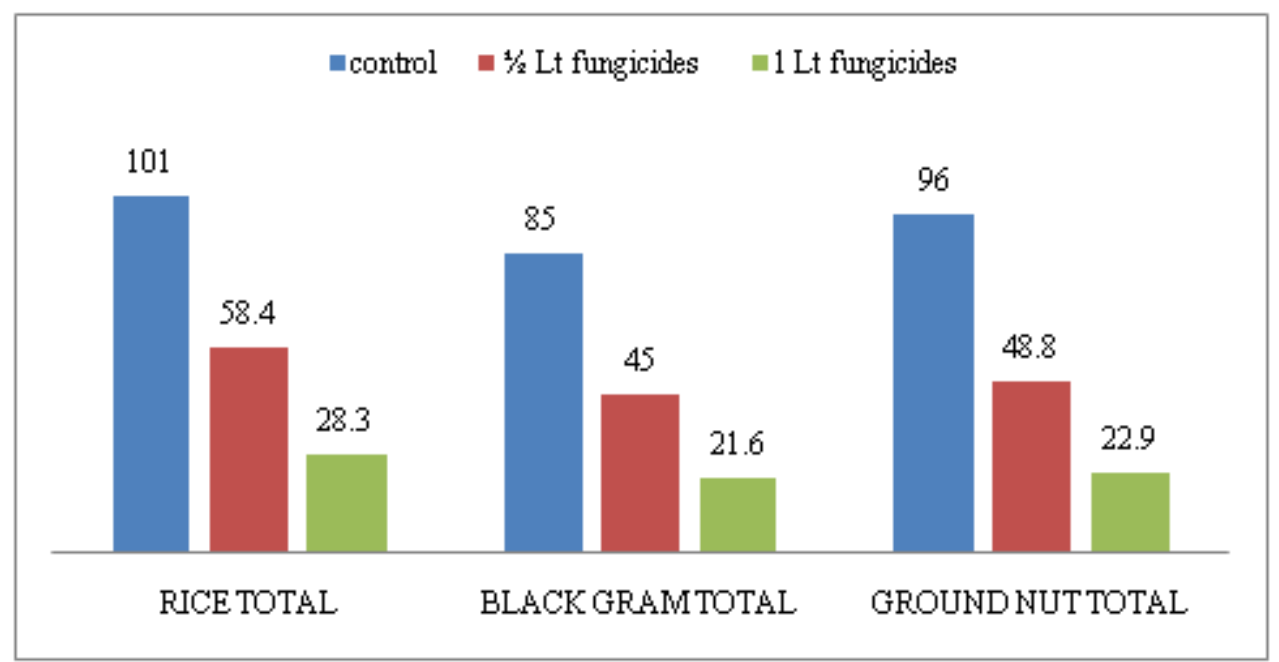

Figure 7: Effect of fungicides

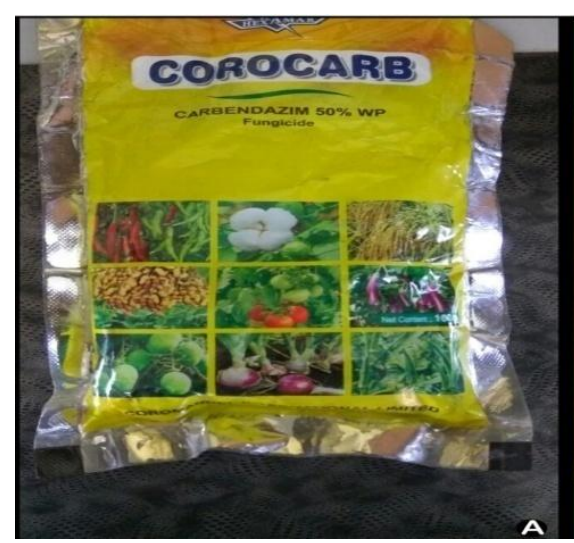

Figure 8: A. Carbendazim

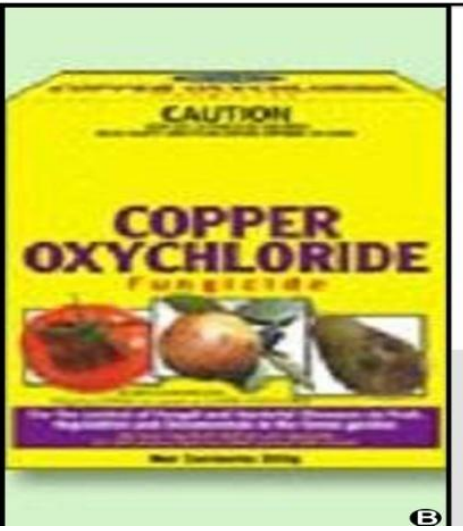

B. Copper Oxy chloride

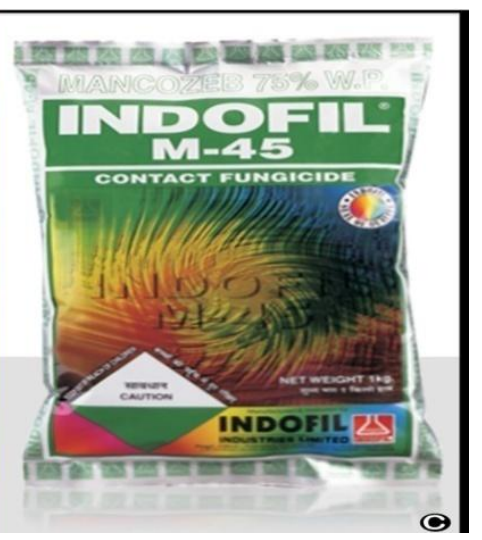

C. Manozeb

Volume 6 Issue 1, January 2017 www.ijsr.net 
International Journal of Science and Research (IJSR)

ISSN (Online): 2319-7064

Index Copernicus Value (2015): 78.96 | Impact Factor (2015): 6.391
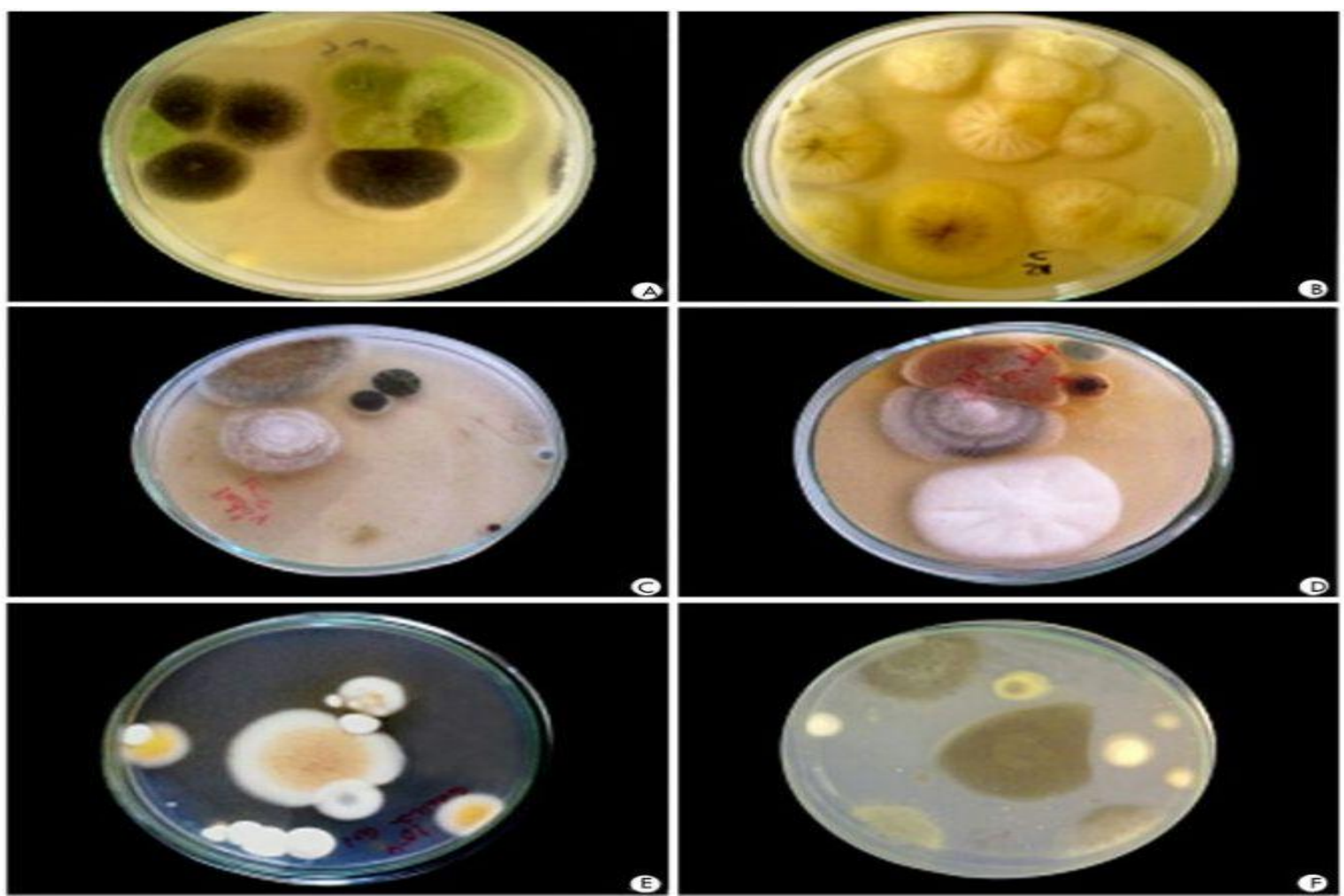

Figure 9: Fungal colonies on PDA from soils treated with fungicides Carbendazim, Copper Oxy Chloride and Mancozeb

Volume 6 Issue 1, January 2017

www.ijsr.net 